\title{
Skin Discoloration
}

National Cancer Institute

\section{Source}

National Cancer Institute. Skin Discoloration. NCI Thesaurus. Code C3327.

Abnormal skin coloration. 